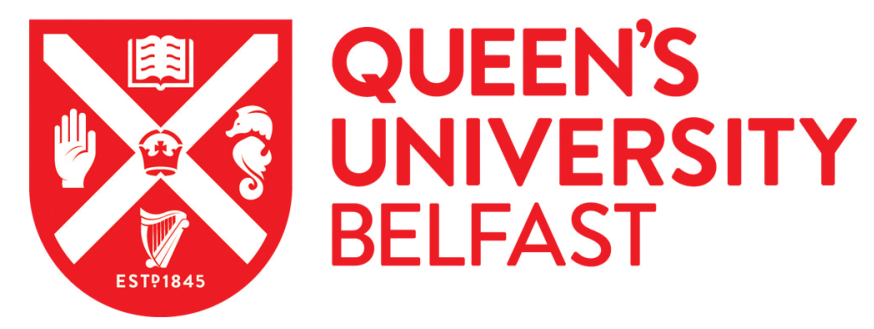

\title{
"Shall we playe the good girles": Playing Girls, Performing Girlhood on Early Modern Stages
}

Lamb, E. (2016). "Shall we playe the good girles": Playing Girls, Performing Girlhood on Early Modern Stages. Renaissance Drama, 44(1), 73-100. https://doi.org/10.1086/685786

Published in:

Renaissance Drama

Document Version:

Peer reviewed version

Queen's University Belfast - Research Portal:

Link to publication record in Queen's University Belfast Research Portal

Publisher rights

Copyright @ 2016, The University of Chicago Press

General rights
Copyright for the publications made accessible via the Queen's University Belfast Research Portal is retained by the author(s) and / or other copyright owners and it is a condition of accessing these publications that users recognise and abide by the legal requirements associated with these rights.

Take down policy

The Research Portal is Queen's institutional repository that provides access to Queen's research output. Every effort has been made to ensure that content in the Research Portal does not infringe any person's rights, or applicable UK laws. If you discover content in the Research Portal that you believe breaches copyright or violates any law, please contact openaccess@qub.ac.uk. 
'Shall we playe the good girles':

Playing Girls, Performing Girlhood on Early Modern Stages

\begin{abstract}
:
This essay investigates the extent to which girlhood functions as a queer category in two theatrical representations of schoolgirls in early seventeenth-century England. It focuses on the depictions of schoolgirls in the anonymous The Wit of a Woman (1604), written for the all-male stage of the professional theatre, and in Robert White's masque, Cupid's Banishment (1617), performed by the young Ladies of Deptford Hall before Queen Anna of Denmark, to examine the intersections of age, gender, sexuality and education in early modern concepts of girlhood. Situating these plays within wider debates about female education and the history of the contested role of performance in the schooling of early modern girls, it argues that they deploy the category of girlhood to demonstrate the subversive potential of educating girls. Yet, this essay proposes, these plays simultaneously reveal the potential agency of young women who manipulate girlhood to claim their distinct sexual, aged and gendered states as girls. It argues that early modern girlhood is a state that might be performed by young women to disrupt normative expectations of feminine behaviour and desire. Placing dramatic representations of schoolgirls and the experiences of schoolgirls on the early modern stage side by side, this essay demonstrates that the schoolroom and performance are sites in which this transgressive potential is realised.
\end{abstract}


The early modern girl is an elusive figure. Challenging to define and difficult to locate in the historical record, she is often only visible or audible at moments of resistance. ${ }^{1}$ In this respect, she is by definition a disruptive figure. This disruptive girl has been the subject of much recent scholarship. In Shakespeare and the Performance of Girlhood (2014), Deanne Williams points out that the girl is frequently a site of independence, wilfulness and resistance and notes that Shakespeare typically uses the term 'girl' when a character's relationship to authority is complicated or troubled. ${ }^{2}$ Jennifer Higginbotham also defines the girl in terms of resistance in The Girlhood of Shakespeare's Sisters (2013). She interprets as girls a range of female characters that are sexually, socially and politically 'resistant to occupying their womanly place within the social hierarchy'. ${ }^{3}$ This 'womanly place' in early modern culture is, of course, determined by the heteronormative expectations of a patriarchal society that emphasised women's roles as chaste maids or virtuous and obedient wives and mothers. This was reinforced by contemporary educational programmes for women, which aimed to instil these virtues and to prepare the young woman on a practical level for her adult role. ${ }^{4}$ Yet this education also equipped these youthful women with the knowledge and a space, imaginative and physical, to forge their selfhoods in ways that challenged the expected transition from maid to wife. This essay focuses on two theatrical representations of schoolgirls who disrupt traditional narratives of feminine behaviour pertaining to the transition from childhood to adulthood: in the anonymous The Wit of a Woman, printed in 1604 and probably written for the all-male cast of one of the professional playing companies, and in Robert White's Cupid's Banishment, a masque put on for Queen Anna at Greenwich by the pupils of a girls' school in Deptford in 1617. It builds on Higginbotham's and William's groundbreaking work on the topic of early modern girlhood to consider moments in which young women manipulate their education to resist what Kate Chedgzoy describes as the 'expectations of heterosexual courtship and marriage' that often shape the 'transition from girlhood to adult life' ${ }^{5}$ It suggests that in these moments young women assert their identities as girls. Although following Williams and Higginbotham in their understanding of early modern girlhood as multiplicitous, it offers a particular reading of the schoolgirl as a queer category, that is as the 'queer child' conceptualised by Bruhm and Hurley that 'confirms neither the comfortable stories of child 
(a)sexuality nor the supposedly blissful promises of adult heteronormativity' ${ }^{6}$ It will propose that the depictions of these schoolgirls as desirable objects but also as desiring subjects destabilises the period's definitions of feminine adulthood and, akin to recent understandings of the queer subject, exposes disjuncture in the expected intersections of sex, gender and desire at this particular stage in the female lifecycle. ${ }^{7}$ This essay thus argues that girlhood, and specifically school-girlhood, is constructed as queer state in these early modern theatrical depictions of schoolgirls.

John Johnson's satirical account of female education in The Academy of Love (1641) indicates a number ways in which the early modern girl is defined in terms of transgressive sexual behaviour in educational contexts. Johnson repeatedly describes the students of the fantastical 'Love's University' as 'witty girls'. ${ }^{8}$ These students doing their degrees under the guidance of Cupid are aligned with 'children [who] begin to squeale out their lessons', take Latin grammar lessons in the language of love and study the 'arte amandi', the arts of love. ${ }^{9}$ Johnson's text concludes with an account of 'Love's library', which allows the girls to further their education in amorous activities through reading Dante, Massinger, Shirley, Sidney’s Arcadia and Shakespeare. According to Cupid, Shakespeare

creepes into the womens closets about bed-time, and if it were not for some of the old outof-date Grandames (who are set over the rest as their tutoresses) the young sparkish Girles would read in Shakespeere day and night, so that they would open the Booke or Tome, and the men with a Fescue in their hands should point to the Verse. ${ }^{10}$

Johnson's account draws on early modern anxieties that educating girls might produce sexually active and disruptive young women instead of virtuous and submissive wives - an idea prevalent in conduct books throughout the sixteenth and seventeenth centuries. Although numerous educators and moralists advocated female learning, many insisted that this learning should be limited. ${ }^{11}$ Vives' instruction to guardians to 'let those bookes be taken in hande, that may teach good manners' and to prevent access to Ovid, 'a Schoolemaster of baudry, and a common corrupter of vertue' was repeated by many over the next century. ${ }^{12}$ Moral tracts commonly warned parents to monitor their daughters' reading and condemned those who 'nursed' their daughters in 'amorous bookes, vaine stories and fonde trifleing fancies' as teaching a 'high path to whoredome'. ${ }^{13}$ The 
concern that literate girls might use their skills to access inappropriate material contributed to an association between female literacy and sexual knowledge. Girls' reading and their school lessons were commonly aligned with lessons in love by detractors and in popular culture. Women were depicted as the primary consumers of romance, particularly in their youth. ${ }^{14}$ Jacque Du Bosc's The Compleat Woman warned young gentlewomen to avoid 'loose pamphlets' describing them as 'cunning lessons, to learne to sinne wittily'. ${ }^{15}$ Du Bosc cites Amadis de Gaule as one example of such material - a text that is also noted by Vives as a book with 'no other purpose, but to corrupt the manners of young folkes' but which was, like Ovid, used as part of some girls' schooling. ${ }^{16}$ The stereotype of the girl's lesson as a space for illicit amorous encounters is also well known from the courtship of Bianca through her lessons in Ovid in Shakespeare's The Taming of the Shrew. ${ }^{17}$ Johnson exploits these associations between educating girls and female eroticism to great comic effect to produce a text that, as Sasha Roberts argues, poses as a piece of conduct literature but in fact was probably written with a male university-educated readership principally in mind. ${ }^{18}$ Yet his use of the terminology of girlhood to describe these female students is noteworthy. These 'witty' and 'young sparkish Girles' are defined as such partially because of their youth but more significantly because of their use (or misuse) of their education to partake in the transgressive act of reading eroticised material in their closets. Being a girl, in Johnson's text, is a performative act that involves an unruly intersection of age, gender, sexuality and literacy. Being a schoolgirl facilitates this act as the educational institution provides not only the lessons but also the site for this communal misbehaviour.

The Wit of a Woman and Cupid's Banishment foreground young females in the context of their schoolrooms and, like Johnson's text, interrogate the relationship between sexual, gendered and aged identity in relation to this schooling. Although The Wit of a Woman humorously explores the perceived associations between female education and eroticism and Cupid's Banishment refutes them, both examine schoolgirls' opportunities to use their learning to negotiate their desires and assert distinct understandings of what it might mean to be a girl. By placing dramatic representations of schoolgirls by boy players in The Wit of a Woman and by schoolgirls in Cupid's Banishment side by side, this essay will explore the ways in which young women engaged with the 
concepts of girlhood emerging in the early seventeenth century. I will propose that while the fictional schoolgirls of The Wit of a Woman play 'girls' in ways that explicitly challenge their fathers' expectations, they ultimately conform to roles of 'good girls' to become good wives. The schoolgirl performers of Cupid's Banishment, however, advocate an idealized version of chaste and obedient girlhood which enables them to resist the transition to marriage and to extend their stay in the homosocial setting of the schoolroom. In both plays, the site of the schoolroom facilitates these performances of girlhood, and it is specifically in performance that girlhood emerges. ${ }^{19}$

An examination of girlhood in this period is challenging. Recent work has clearly established that concepts of childhood in early modern England were gendered and that boys and girls experienced childhood differently. ${ }^{20}$ Yet the language of girlhood had not developed to the same extent as the language of childhood or boyhood by the early seventeenth century. Shakespeare may, as Deanne Williams points out, have used the term girl about sixty-eight times but its meaning was varied. ${ }^{21}$ Jennifer Higginbotham has persuasively argued that although 'girl' was commonly used to refer to a female infant, it only fully evolved as term to designate age by the mid-seventeenth century. The terms used in relation to female childhood and youth, she points out, were diverse and interchangeable and often young girls were defined by their sexual status rather than their age. Girl and girlishness more commonly referred to a set of performed behaviours that related to females in liminal social and sexual positions and frequently signalled illicit female sexual desire. ${ }^{22}$ This is discernable in Johnson's use of the term for his fictional female students. The terms that I will use throughout this essay - schoolgirls and girlhood - in relation to the young female figures in The Wit of a Woman and Cupid's Banishment might be contested on the grounds that they were not used specifically to mean girls at educational institutions or in relation to aged categories until the early eighteenth century. ${ }^{23}$ However, I propose that these dramatic texts shed light on a gendered understanding of youth that incorporates age, education and sexuality. They depict young women who perform girlhood: that is, who exploit their states as educated youths to produce their gendered and sexual identities in ways that challenge typical uses of the term 'girl' in the period. Girlhood, therefore, is not only a state that disrupts expectations of ideal feminine behaviour and desire, but is itself open to reinterpretation in ways that complicate the monolithic 
notion of being a girl suggested by the misogynist formulations of Johnson and various early modern commentators on female behaviour. Focusing on the figure of the schoolgirl, this essay will explore the extent to which the schoolroom in particular enables the production of a queer girlhood, a sexually aware and temporal state that is resistant to the anticipated transition to adult heteronormativity commonly controlled by male authority figures in early modern culture. It draws on Judith Halberstam's theorisation of queer subcultures which allow their participants to 'believe that their futures can be imagined according to the logics that lie outside of those paradigmatic markers of life experience - namely birth, marriage, reproduction and death' to read the schoolroom as a queer space in which these schoolgirls imagine and, in the case of Cupid's Banishment, negotiate alternative futures. ${ }^{24}$

\section{Playing the Girl: The Wit of a Woman}

The significance of the early modern schoolroom for young women has not been fully investigated. Studies of schooling in the period have tended to focus on male education, noting (accurately) that while many early modern women received an education this more often took place in informal settings beyond the institution of the school. ${ }^{25}$ Yet the potential importance of the schoolroom as a space for instilling and testing the limits of feminine identities is manifest in The Wit of a Woman. Presenting various attempts at courtship and setting the wits of young men and women against those of their fathers, this play follows the format of numerous romantic comedies in the period in presenting generational conflicts and romantic entanglements through to a concluding scene in which all of the young characters are paired off for marriage with, as the prologue had promised, 'Age ...cozened' and 'Youth ...pleas'd'. ${ }^{26}$ However, it differs in prioritising the young female characters. The actions of the four schoolgirls or 'wenches' progress the narrative and they outwit all of the male characters so that each gets her chosen husband. Set largely in their schoolroom, the play opens with a discussion of their work with their schoolmistress, Balia. Their schooling includes needlework (stitching, making cushions and clothing) and writing as well as lute playing and dancing. Specialist masters (the young suitors disguised as teachers) are brought in to provide extra lessons in reading and writing and dancing in 
a later scene. These girls are immediately presented as participants in a gendered programme of schooling common in early modern England.

Education differentiated between the sexes even from the earliest stages. Donne's instruction that 'as your sons write by copies and your daughters by samplers, be every father a copy to his son and every mother a sampler to her daughter' is indicative of the sex-specific modes of literacy instruction. ${ }^{27}$ Although male and female children often learned to read together, either through informal instruction in the home or at the petty school, there were variations in the content and materiality of the texts recommended to girls. The needlework sampler, as Donne suggests, may have functioned as an alternative $\mathrm{ABC}$ text for early instruction in reading and writing. ${ }^{28}$ These distinctions increased at more advanced levels of instruction. While many boys gained an education in Latin, rhetoric and the classics that varied according to their social status, girls' informal and formal schooling was characterised by the combination of practical skills in needlework and household accounts and basic literacy. This was often supplemented, particularly for girls from more wealthy backgrounds, with instruction in dance, music and sometimes grammar and languages. In many instances this education was provided in the home but girls' schools became increasingly common in England throughout the seventeenth century. ${ }^{29}$ The extant curricula for these early schools indicate the continuing education of girls in this broad range of domestic and academic skills. A similar syllabus is presented in Richard Brome's later play, The Queen and Concubine (performed c. 1635), in which an exiled Queen becomes a schoolmistress to earn her living among a rural community. She teaches one girl 'that knew no letter in the Book' to read, alongside writing, needlework and clothes making, and music and dance for recreation. ${ }^{30}$ Balia's supervision of the education of this group of girls in her home, positioned somewhere between individual tuition in the girl's household and the formal public schools, and the instruction she provides in basic literacy and needlework combined with supplementary lessons from specialist teachers was not unusual. Despite the marked difference in the settings of The Wit of a Woman and Brome's later play, the subjects taught in the finishing school for young ladies hoping to become good wives and the school for apprentice clothes-makers are markedly similar and suggest a level of parity in the education deemed suitable for girls from different social backgrounds. ${ }^{31}$ 
These common methods of schooling girls are brought to the fore through a series of schoolroom scenes and are positioned within a wider engagement with contemporary debates on female education throughout the play. One of the primary aims of the formal education of girls in the late sixteenth and early seventeenth centuries was to instil skills required for marriage and this is reflected in the play's fathers' insistence that learning should produce good wives. ${ }^{32}$ They compare the talents that each of their daughters have acquired in order to promote them as potential wives. Yet one father is concerned that this schooling 'marre[s] huswifery' and 'aske[s] cost' (B3v), and another worries that 'writing in a wench may make ill work with a man' (B3V). The play raises both sides of contemporary debates on female education: the benefits of schooling for producing virtuous, well-mannered wives versus the danger that knowledgeable daughters might behave improperly. The fear that their schooling might provide opportunities for the euphemistic 'ill work' is developed further when the four young men of the play disguise themselves as a writing master, a dancing school master, a painter and a doctor in order to access the school and woo the girls. The schoolgirls of The Wit of a Woman mock rather than succumb to the advances of their young suitors. When Veronte, disguised as a writing master, sets Erinta to copy a verse on love that he has written, she mocks him with 'why thou sweet Schoolemaster, all my lesson is of Love, a sweet Love lesson' (D2v). This knowing schoolgirl does not engage in this courtship but undercuts the efforts of her young suitor. The other girls similarly question their disguised suitors until they reveal their love and then partaking in a 'merrie' dance they leave with the promise 'at your next coming wee will talke further' (D4r - my emphasis). Reluctantly the young men admit that 'our sutilty found out, our profession, wil be unprofitable' (D4r). From this point on, they adopt a passive role in the courtship and allow the schoolgirls to devise the plots that will allow them to marry. As Jean Lambert points out in her analysis, the play both mocks and endorses contemporary concerns about schooling girls. ${ }^{33}$

These schoolgirls illuminate another feared-consequence of female education: that of acquiring knowledge in matters of love and male behaviour. The girls claim that the sources of their knowledge are tales and reading. Finding themselves desired by the four elderly fathers but in love with the four young sons, the schoolgirls set out in the opening scene to use their wit to 'rule the wit 
of a man' (A4v), escape their elderly suitors and gain their choice of young ones. When Balia leaves them 'awhile to yourselves' to 'take your pleasures' (A4r) they discuss their 'melancholy' (A4r), share their secrets and impart their knowledge of male behaviour. Gianetta has 'heard' tales in which women are played with 'like Apes' and their houses 'kept as a prison' (A4v). Erinta, however, counters this with her insights gained through reading. Claiming 'for if ever thou hast red stories, or markt courses, then thou wilt finde that al the wit they have, all the bookes they read, al the courses they take is but to please us' (A4v), Erinta shares this apparent wisdom about male behaviour (their wit, action and reading practices) to encourage the schoolgirls to, in her words, 'playe the good girles' and 'keepe one an others counsell' (B1r). Acting as 'good girles' enables them to fool their fathers by hiding their shared secrets and disruptive behaviour so that they can ultimately outwit the play's patriarchs and young men. They thus deploy one concept of girlhood, the role of obedient child desired by their father, to facilitate their behaviour as disruptive girls, managing their own desires. They do this at various points during the play. Realising that they are the objects of desire of the old men, they resolve that through their 'wittes' they 'will cosen them of their sonnes, of their wealth, and of their wits... and make them all pleased, in spight of their owne hearts' (F1r). By pretending to accept the interests of their suitors until their 'portions' (F1v) are handed over, devising a 'plot for the wedding' (F2v) and refusing to let the young men in on the 'plot laide for your good' (F2v), the girls manipulate the young and old men to ensure that they get what they want and 'have a day of it, that shall bee spoken on when wee are dead' (F4v). They gleefully celebrate this behaviour but in doing so recognise its status as extraordinary. The ability of these schoolgirls to perform girlhood to manage their own erotic desires in a move towards marriage is depicted by the play as exceptional. While on the one hand the play charts a common tale of the transition of girls from the feminised communities of childhood, represented here by the schoolroom of Balia's house in which they live as 'sisters' overseen by a 'mother'-schoolmistress (A4r), it complicates this narrative through the depiction of the girls' wit. ${ }^{34}$ It is through their knowledge of sexual desire, and of the legal and economic ramifications of marriage, or what the play’s title and prologue term a 'woman's wit' (A2v), and through the sharing of this knowledge in 
the schoolroom, that these schoolgirls on the cusp of adulthood manage their own erotic and economic futures.

To some extent, this plot line reproduces concerns about girls' education and reading practices. Moralists implied that 'lascivious stories’ might lead to inappropriate sexual behaviour specifically because, according to Jacques Du Bosc, these stories leave their mark on susceptible youths and although 'wee know well, they are but fictions, yet nevertheless they truly move being read'. ${ }^{35}$ The real danger is that girls will not be able to distinguish between fiction and reality and in Du Bosc's formulation this danger is increased in the case of the youthful female. The conflation of the stories read and the course of action taken by the schoolgirls of The Wit of a Woman engages with these misogynistic fears pertaining to uncontrolled and uncontrollable female reading, and the particular inability of girls to distinguish between positive and negative examples or between fact and fiction. The potential threat of such reading practices is conveyed through the schoolgirls' appropriation of the stories they have read and the tales they have heard when they set out to 'governe men' (A4r). This potentially reinforces the misogynist concept of girl as transgressive reader. However, the schoolgirls are not condemned for this course but instead are the heroines of this comedy. They achieve their aims by using their learning with relative ease. As a servant in the play notes, 'olde men may teach to spell, but young folks will put together' (C3v), referring to the practices of teaching basic literacy in the period by teaching letters and then common groupings of letters which provides children with the tools to read any word. The servant knowingly hints at the agency that may be acquired by youth through even this basic instruction. Knowledge of basic literacy and of fictional tales enables these schoolgirls to instigate courtships and pursue love interests in ways that disrupt their fathers' intentions. The opportunities provided in the schoolroom and the space of the schoolroom enable behaviour that challenges expectations of age- and genderappropriate experiences of desire.

The schoolgirls' deployment of the knowledge gained from stories is particularly interesting because they are not the only characters to draw on such sources. The young men similarly claim their knowledge of female behaviour from tales. Filenio tells 'a short and a true tale of a fine Taming of a Bedlam queane who would never let her husband be at quiet: and after order 
taken with her, became the best wife in the world' (G1v). Although this becomes the 'lesson' that they seek to 'perfect by heart' (G1v), they are not initially as successful as their female counterparts. The girls learn from their stories and use them to their advantage. They read what they want, rejecting the advances of the older men with 'Shall we al studie olde Chronicles? Bee bound prentizes to Age during life, and marry our selves to silver heads, and snowie beardes' (F2v). By aligning the choice of a suitor with that of reading material, the girls evoke the image of the reader feared by fathers and moralists. On the other hand, they demonstrate a control over these decisions that is celebrated in the play's final scene. One father admits at the play's conclusion that 'it is vaine to talk to the wenches' as 'they will have it if they set on it' (H1r). The elderly men accept that 'the wenches by their wits have cousned' them of their wealth and escaped marriage to them (H1r). The terminology of 'wenches', a diminutive but affectionate term reinforcing that the girls should be junior not only because of their youth but also because of its associations with service, is complemented by the repetition in this final scene of 'youth' and 'age'. ${ }^{36}$ This language of age reinforces the mastery of youth over age that was set up in the prologue. The wenches, the fathers state, 'have their loves, the Boyes have our handes and we have the whirligige' (H1v). Their sons and daughters have gained their desires and the fathers are left with nothing but 'whirligigs', suggesting that the irregular behaviour of the young characters has ultimately reversed the play's hierarchies as the fathers become children through this image of the spinning children's toy.

The girls' behaviour in The Wit of a Woman is dependent on two factors: the schoolroom setting and the manipulation of multiple concepts of girlhood. The schoolroom provides education but also constitutes a space in which the girls have a voice. It is here, in the community of 'sisters' (A4r), that they vow to 'playe the good girles' (B1r) and undertake to manage their own 'plot' (F2v). The shared experience of the schoolroom facilitates their expression and pursuit of desire and this subcultural space offers, what Halberstam terms, an alternative to 'family time and family life' ${ }^{37}$ It is specifically the performance of childhood within this culture, playing a 'girl', that Balia's pupils use to their advantage. The self-reflexive terminology of 'playing' girls and laying 'plots' comically alludes to the performance context of this play. Although nothing is known about its authorship or performance, it is likely that it was written with one of London's professional 
theatres in mind and, if it was performed at all, boy actors would have played the roles of the four schoolgirls. ${ }^{38}$ The act of 'playing girls', therefore, is not only undertaken by the schoolgirls but by the boy actors, disclosing the nature of girlhood in The Wit of a Woman. It is doubly performed. Girlhood is a state that the schoolgirls can put on at will and appropriate to facilitate their behaviour beyond the watchful eyes of their fathers and teacher. Being a girl is also performance, in the theatrical sense, for the boy actors on the early modern stage. The equivalent abilities of these actors, historical and fictional, to take on girlhood suggests in one sense that this youthful category is open to all. Yet this allusion to layered performances by boys and girls of multiple states of childhood - being a girl, a schoolgirl, a wench or even a wag - also indicates the extent to which these states are assimilated in this play. If the metatheatrical puns allude to the boy actors' suitability to perform female roles, the young men of the play also perform childhood. ${ }^{39}$ They avoid their fathers' admonitions for courting the girls by assuming that the fathers 'will thinke we have bin together playing the wagges and so leave us to our better courses' (D4v). The state of childhood, being girls or wagges (a term that implies mischievous behaviour in addition to signifying male youth), forges a notional site in which the youths of The Wit of a Woman can playfully pursue their own desires. The merged sites of schoolroom, performance and childhood create an imaginative space, which functions in similar ways to later girls' culture theorised by Sally Mitchell as a 'provisional free space' in which young women bordering childhood and adulthood can recognise a state of girlhood and exploit its 'discord with adult expectations'. ${ }^{40}$ Yet, when the schoolgirls exploit this space it is perceived by the play's male characters to be a transgressive and cross-gendered act. The schoolgirls may claim to 'play the good girles' but the young men recognise the disruptive potential of their behaviour in claiming that 'women have strange wit in these daies, for if they bee disposed to play the wagges, it is not almost to be thought what they can bring to passe' (F4v). Although the young men adopt a similar strategy of acting as boys or wags to manipulate their fathers' wills, the struggle for authority between these male characters and their fathers is almost expected from characters on the verge of manhood. In contrast, the female characters' habitation of the temporal and disruptive space of girlhood dismantles not only expectations of a submissive and non-desiring childhood but of a similarly 
constrained patriarchal ideal of early modern womanhood, which advocated marriage for women without facilitating female desire or choice in this process. The girls test the boundaries of gendered behaviour within these various categories of masculine and feminine childhoods to assert their youthful authorities and to challenge the aged and gendered hierarchies of a patriarchal society. By playing well-behaved daughters, which involves a manipulation of both aged and gendered roles, they negotiate their own transition to adulthood and gain the husbands of their choice.

The fact that the fathers, young men and the schoolgirls all account for their autonomous behaviour in terms of youth might be seen as a means of rendering the girls' actions acceptable: associated with categories of youth it becomes something that is left behind when they become women. ${ }^{41}$ It might be read as part of what Halberstam views as a standard narrative of maturation in which adulthood emerges from 'the dangerous and unruly period of adolescence'. ${ }^{42}$ Their act of girlhood is constructed, to some extent, as the playful revels of childhood, acceptable as long as they marry appropriately. Although the girls do not marry the old male suitors, they are happily paired off with the eligible young men at the play's conclusion. Marriage, unsurprisingly, has been the fathers' aim from the start of the play. One father states in the opening scene that his daughter will not 'part from her mistresse, till she have a master that she may be bold with' (B3r). Erinta is diagnosed by one of the fathers, a doctor, as 'inclined towards the greene sicknes' $(\mathrm{Cv})$ and the 'something' that he offers to minister to her we quickly discover is himself. Poised between childhood and adulthood in terms of biology and sexuality and institutionally towards the end of their schooling and ready for marriage, the female characters of The Wit of a Woman easily negotiate their way into adulthood in the ways desired by their fathers, despite their apparent unruliness. Although the sisterhood and learning of the schoolroom allows an element of agency in managing this transition in ways that challenge the established order of early modern society, the queer potential of the schoolroom is suppressed as they move from school to marriage. The disruptive performance of knowing girlhood by these schoolgirls is sanctioned as long as the result is marriage - a conclusion that is supported generically by this comedy. Although the carnivalesque world in which girls outwit men and in which fathers are aligned with children persists until the 
play's final moments. The marriages promised at the conclusion suggest that the narrative that ultimately shapes the girls' behaviour is the 'true tale of a fine Taming of a Bedlam queane' (G1v) recounted by Filenio earlier in the play. Despite the girls' deployment of their lessons and their reading, it is the boys' stories that are realised. Ultimately, therefore, boys are at the narrative and theatrical centre of The Wit of a Woman's story of girlhood. The potentially disruptive queer girlhood enacted by the female characters is contained by both genre and the gendered composition of this theatre.

\section{Performing Girls: Cupid's Banishment}

In this respect, Robert White’s Cupid’s Banishment offers a fascinating alternative example of girlhood as the space of the schoolroom and of the drama allow a group of schoolgirls to imagine alternative futures that not only disrupt normal order but lie outside Halberstam's paradigmatic markers of life experience. ${ }^{43}$ In this masque schoolgirls are once again depicted in relation to education, youth and sexuality. However, in this case schoolgirls are implicated not only as characters in the cultural performance of girlhood but also as performers in the theatrical depiction of this state. Performed before Queen Anna of Denmark at Greenwich in May 1617, this masque is the 'revels' of the 'young Gentlewomen of the Ladies' Hall'. ${ }^{44}$ Ladies' Hall was a public English girls' school but nothing is known about it beyond the information contained in the masque manuscript prepared by the schoolmaster-author, Robert White. From the content of the masque, it seems that the school, like other formal and informal modes of female education, educated young gentlewomen in song, dance, needlework and etiquette, and possibly also in memory and recitation. ${ }^{45}$ According to White's dedication to Lucy, Countess of Bedford, the performance presents the 'choosing of a king and queen by Fortune’s doom, which is a sport our little ladies can use on Candlemas night' (p. 83). Occasion's opening speech repeats this claim calling it a 'sport' that 'the lovely crew / Of Ladies' Hall' 'yearly celebrate' (l. 30). The masque bears remarkable similarities in this respect to the dramatic performances and revels celebrations common in early modern boys' schools in the period and also hints at the wider practice of performance in female educational institutions. ${ }^{46}$ 
The pupils of Ladies' Hall are the main performers of this piece. Of the twenty-four pupils named in the text, it is likely that many are the daughters of members of the court and two are the goddaughters of the Queen. ${ }^{47}$ While it is difficult to determine the exact identities of these performers, extant biographical information on some of the girls indicates that they range in age from at least 7 to 12 years old. ${ }^{48}$ Like the schoolgirls of The Wit of a Woman, these female performers are on the cusp of adulthood and approaching marriageable status. ${ }^{49}$ These girls follow the example set by Queen Anna and her female courtiers, who frequently danced in masques between 1604 and 1611. In this respect, the performance constitutes a form of flattery and a mirroring of these elite models - an educational method widely advocated for early modern girls. ${ }^{50}$ It potentially functions as a form of training in the behaviour of the courtly lady and as a means of seeking a position in the court. The girls, for the most part, follow the practices of Anna in taking the dancing roles of masquers but with some differences. Unlike typical Jacobean female masquers the girls are present on stage throughout the performance and these girls sing as well as dance. 'Mistress Deborah Draper' performs the silent role of the Queen of the revels and 'Mistress Ann Watkins acted Fortune', a speaking role and an unprecedented example of female 'acting' in the court. ${ }^{51}$ Men and boys perform the rest of the speaking parts. White himself probably plays the part of Occasion (appropriately introducing, overseeing and concluding the presentation of his young pupils). The inclusion of the twelve-year-old Richard Browne, son of a local dignitary, and of Charles Coleman, a member of the King's music, among the performers suggest that a mix of elite and professional boys acted alongside the members of the school. ${ }^{52}$ This masque brings together performers of different age groups, sex and social backgrounds, but it is occupied largely by children as performers and as the characters of the 'waggish' 'little boy' Cupid, Mercury, the children of Bacchus and the nymphs of Diana.

Cupid's Banishment has recently been the focus of much critical attention in the context of female performance. While scholars have cited connections with a diverse range of performance contexts (court, convent and professional theatres) as influencing this exceptional instance of female acting, they all agree on the agency allocated to women in this performance. ${ }^{53}$ Sophie Tomlinson, for instance, has recently read White's masque as 'an instrument of self-assertion for his 
young female charges' ${ }^{54}$ As scholars have suggested, this was possible because of the convergence of a number of factors including the performer's juniority and the masquing stage as a space for training the young courtly lady. ${ }^{55}$ I want to build on recent analyses of this masque to suggest that it is the performance by schoolgirls that specifically enables an assertion of youthful femininity: a performance of school-girlhood. The identities of these girls as pupils of the Ladies' Hall pervade this masque. They perform the roles of Diana's nymphs but as masquers they also represent themselves as pupils of the school. ${ }^{56}$ The performance is an opportunity for the girls to display the results of their schooling. The nymphs sing. They perform set dances including three towards the end that are choreographed to form the words 'Anna Regina', 'Jacobus Rex' and 'Carolus P' for the Queen and the absent King and Prince. After this two of the girls (the Queen's goddaughters) step forward to present needlework gifts ‘beginning with the first letters of the Queen’s name’ (l. 301, s.d.): acorn and rosemary. These 'timely fruits of their chaste labours' (l. 297) are likely the work of the girls themselves. The masque thus climaxes with the display of the modes of literacy education possibly used in the school. Dance and needlework are presented here as distinctly gendered modes of writing that produce the feminine identities of these scholars through their learning. The herbal emblems on the samplers are also significant in this respect as both herbals and emblem books were recommended in the period as appropriate reading for young girls. ${ }^{57}$ Cupid's Banishment puts these accomplishments of female education on show: celebrating them and seeking the approval of the Queen. The masque concludes by drawing attention to its own status as the product of the girls' education, the result of their 'homespun' muse and 'own' 'action' (l. 332), and by asking that Anna 'shine upon our childish sport' (l. 330) and grace the schoolgirls, their teacher and their school: ‘Our nymphs, Occasion, and our Ladies’ Hall’ (l. 334).

It is not surprising that a schoolmaster-author represents the benefits of schooling girls. In order to make his case for the advantages of the school, White incorporates responses to potential critics. The masque repeatedly rejects the notion that the schoolroom might lend itself to any sort of inappropriate behaviour. Even partaking in a revels' performance is defended when White insists in the dedication that what is presented is 'no marriage but a form of uniting chaste hearts to shew a 
defiance to Cupid and his contracts' (p. 83). The stage directions reiterate this claim. Deborah Draper as the Queen of the revels, for example, is described as:

attired all in silver tinsie showing that she was one of Diana’s train and that their revels did wholly tend to Chastity, being a sport the goddess and her nymphs did use in bowers and retired places without any prejudice to virginity or scandal to any entire vow (l. 195 s. d.).

The setting of the schoolroom, White insists, offers a protected space for this perhaps otherwise unacceptable participation in carnival or performance and sanctions it in the public and politicised space of the court. The girls' revels are not those of Cupid but a form of pleasure that does not affect their chastity.

Nonetheless the threat of erotic and illicit female desire pervades the performance, primarily through the staging of Cupid. Cupid comes alone at first and then under the protection of Bacchus and his children to 'Summon young spirits to a jubilee. / Invite fresh youth to some amorous scene' (ll. 40-41). The masque acknowledges the idea that is depicted comically in The Academy of Love and The Wit of Woman, namely that educating girls might stand as an invitation to the wanton activity. However, it does so in order to reject it. Occasion initially attempts to expel Cupid insisting that 'This is no time nor place for Cupid's wiles' (1. 59). Diana (played by Richard Browne) subsequently dismisses him 'to some amorous court' to 'tutor / Wanton ladies how to woo' (ll. 100-101) and to:

Invent some antic fashion how to please

His mistress' eye with vows and endless protestations.

Make him swear he loves her dearly

Though indeed affecteth nothing less. (ll. 103-106)

Diana's description of Cupid's 'practices and chief exploits' (l. 107) undermines him and mocks the behaviour of men in love. Her speech implies that in rejecting Cupid the nymphs are not susceptible to the insincere wooing of men. Like the schoolgirls of The Wit of a Woman, they are too well educated for such behaviour. The subject of ridicule in both texts is the behaviour of male suitors rather than the actions of schoolgirls. 
Although Cupid temporarily leaves the stage after this speech, he soon returns. Ultimately it is the nymphs who must expel him from their bowers, and by extension from their schoolroom. This is a crucial moment in the masque as eight of the girls as 'Driades' or wood nymphs 'conquer' Cupid. Dressed in 'green garments' with flowers and garlands about their 'dishevelled' hair they come with darts in their hands, 'fall' in to a dance during which they surround Cupid, put Actaeon's head upon him and then 'fall off threatening him with their darts when he offers to resist' until they 'chase him forth into the woods in violence and banish him that presence' (l. 218, s.d). Although scripted by the headmaster and probably choreographed by Master Onslo (described as a 'tutor to the Ladies' Hall’ [1. 149, s.d.]), the schoolgirls are implicated in this moment via their performing bodies. ${ }^{58}$ The strange violence of the dance is notable. Going against models of feminine decorum and comportment, the young performers transgress the ideals of feminine behaviour in the moment that they assert themselves in this expulsion of the young god of desire. ${ }^{59}$ Through their dance and their 'violence' they expel Cupid from the stage, rejecting his wanton temptations. They emphasise their role in his banishment by celebrating with a song - a medium through which they can express their rejection of 'Cupid and his tyranny' (l. 229). Their voices are authorized through a comparison with Philomel, as they sing 'Hark, hark, how Philomel ...descants still on chastity / The diapason of her song is Cupid's gone' (ll. 219-223). The masque, as Sophie Tomlinson points out, co-opts Ovid in the crowning of Cupid with Actaeon's head in the violence of the dance and in this deployment of Philomel, at once an image of 'muteness and inarticulacy and female eloquence', to facilitate the girls' voices. ${ }^{60}$ It is particularly interesting that the girls assert their decision to reject Cupid and remain chaste via an author frequently invoked as dangerous reading for girls and as threatening their virtue. The schoolmaster, on the one hand, selects from and rewrites Ovid's Metamorphoses for his young female pupils. On the other hand, the girls draw on the books of their education for models that enable the assertion of their states as schoolgirls who reject Cupid.

It is in rejecting Cupid that the girls assert their version of feminine youth. Unlike The Wit of a Woman, Cupid's Banishment does not explicitly acknowledge the existence of the 'girl' as a distinct state but it does repeatedly foreground the pupil's youth in relation to their sexuality. ${ }^{61}$ Cupid's intrusion into the girls' bowers hints that the pupils are on the cusp of adulthood, or at least 
of sexual maturity. Cupid is a figure who, Kate Chedgzoy points out, foregrounds the 'complexities of establishing and then transgressing the boundaries between gendered and sexually marked categories of age and status ...poised in his representation as an adolescent between childhood and adulthood'. ${ }^{62}$ Viewing the girls as 'young spirits' (1. 40), and 'fresh youth' (l. 41) ready for his temptations, Cupid highlights their liminal states. He challenges them by calling them 'milksop Ladies' (l. 119), insulting them as spiritless and infantile, and condemning their 'squeamish, affected niceness' (1. 211). The schoolgirls are, Cupid implies, ready for sexual maturity but are standing in the way of this development through their coy attitudes. Cupid's language suggests that in refusing his advances these schoolgirls choose to remain children instead of becoming women, characterised here by sexual knowledge and experience. Instead the girls produce 'alternative temporalities', remaining girls by reimaging the relationship between age, physical maturity and sexual or marital status.

Physical development is implied in this performance by the presence of the young female body, a representational strategy evidently not available in The Wit of a Woman, and is emphasised through the use of costume. The wood nymphs' green attire signals the biological transition from childhood and adulthood frequently conveyed on the early modern stage through the symptoms of greensickness. Allusions to the girls' greenness or to the symptoms of the disease were commonly invoked in drama to focus attention on the processes of puberty on the young female body as it reaches sexual maturity and were often interpreted by male characters, especially fathers (such as the Doctor in The Wit of a Woman), as an impetus to marriage. ${ }^{63}$ It is significant, therefore, that the girls who chase Cupid from the stage are dressed in green - the colour associated with this stage of biological development although interestingly also signifying erotic appeal and even prostitution. ${ }^{64}$ These elite young women clothed in green with 'dishevelled hair' and 'arms half naked' (1. 218 s.d.) are thus eroticised: their sexual maturity is foregrounded and displayed enticingly to the audience. They are both desirable and desiring. Yet through the narrative of the masque they resist the biological and sexual development from girlhood to womanhood implied by this costume and the body on stage. In this performance they take control of their own sexual development to retain their 'virgin's vow[s]' (l. 110) and 'Modesty' (l. 28). 
Not all of the schoolgirl performers are dressed in green. The nymphs who perform the final masque dance are instead, like Draper, clothed primarily in 'white tinsie to show their defiance to CUPID; and to signify their chaste meeting' (l. 284, s.d.). It is possible that these girls were older. $^{65}$ In this case their costume might signify an earlier rejection of Cupid and ongoing commitment to chastity. These female performers in white also have 'dishevelled hair' and appear with 'their breasts naked with rich jewels and pearls' (l. 284, s.d.). Like the green-clothed wood nymphs, they are marked as erotic entities and they too have chosen to reject Cupid. In this respect, the masque evokes the convent setting, another space in which female performance was sanctioned. ${ }^{66}$ This setting is further implied by Diana's introduction of these nymphs as 'sacred sisters’ presenting a 'chaste scene' (ll. 280-281). While the convent setting would have permitted the girls to institutionally prolong their dedication to chastity, this is no longer an option in the postReformation context. Diana informs the audience that these nymphs have emerged from her bowers for the occasion: they have 'retired form the leavy [sic] woods / Have left their wonted habits all of green' (1l. 286-287). Yet they have retained their honour. The movement from the secluded and natural setting (or from the schoolroom) to the court further indicates a development out of childhood in to an irregular feminine adulthood; an adulthood characterised by chastity instead of by Cupid's amorous activity. This stage offers a space in which these young women, presented as both desirable and desiring, can explore an alternative articulation of female desire in relation to age that cannot be categorised within the post-Reformation options of maid, wife or widow.

In this sense, these young women are analogous to the 'queer virgins' of the early modern theatre, who, according to Theodora Jankowski, refuse to be part of the sexual economy or defined by their reproductive capabilities through their decision to remain virgins. ${ }^{67}$ The girls of Cupid's Banishment similarly opt to live beyond heterosexual gender paradigms through their commitment to chastity. Yet, they are also distinct. These schoolgirls assert a queer virginity embracing identification with their school and sisterhood. But this is not the 'perpetual' virginity of many of Jankowski's examples; it is a temporal state. ${ }^{68}$ The masque repeatedly highlights that the performance is temporary. The twelve masquers are momentarily positioned as crossing the 
boundaries from the schoolroom to the court. Their final song tells us that as 'cruel Time doth slide so swift away ... we must home unto our shady bowers' (1l. 309-310). Time is a crucial theme throughout the performance. It is present in the aging bodies of the girls and in their potential states as future members of the court that signal a developmental and forward movement. ${ }^{69}$ Yet it is also introduced as restrictive and enforcing a reverse cycle. When Fortune, acted by Ann Watkins, appears on stage holding her wheel she notes that 'We are engaged to Time for this occasion' (l. 139) and pre-empts the inevitable return to the schoolroom. As noted, Fortune's brief eight-line speech is striking as an unprecedented example of female speech on the court stage. Yet it is presented here as appropriate within this school performance. Although most extant curricula from early girls' schools do not recommend dramatic activity to schoolgirls, there are some indications that English girls may have participated in speaking theatricals in their schools. The fact that the revels of the Ladies' Hall may have been a common part of the school calendar suggests that girls may have participated in dramatic entertainments beyond this one instance. ${ }^{70}$ Mary Ward's schools for English Catholic girls in exile on the continent in the seventeenth century also lend support to this suggestion as it is likely that training in dramatic performance formed an essential part of the girls' curricula at Ward's institutions in a similar manner to boys' schools. ${ }^{71}$ It is possible, therefore, that Watkins' speech was, like much of the performance, akin to a school exercise: a way of practising learning in memorization, recitation and delivery. It is, therefore, Watkins' particular identity as a schoolgirl that permits this speech. Watkins' voice, dependent on her position as a schoolgirl, works alongside the performing bodies of her peers to assert her girlhood against the other tropes of the play signalling a development through age and sexual maturity to womanhood. These schoolgirl performers demonstrate what Kathryn Bond Stockton has termed 'sideways growth': an alternative to the normative 'growing up', which locates pleasure and vitality in the 'back-and-forth of connections and extensions that are not reproductive'. ${ }^{72}$ Through their commitment to chastity, and additionally to their schoolroom, these young women occupy a 'queer space within the early modern Protestant sex/gender sytem', which, as Jankowski points out of early modern virgins, allows them to opt out of patriarchy. ${ }^{73}$ Although not necessarily 'perpetual virgins' 
these schoolgirls constitute queer girls, deferring for now the transition to heteronormative adulthood.

As many theorists have noted, the child-figure by definition disrupts the normative subject. ${ }^{74}$ Defined by his or her potentiality and in the process of becoming-adult, the child who does not or has not yet realized this potential constitutes a 'flawed' child or incomplete adult, existing outside accepted categories. ${ }^{75}$ In their refusal to progress or 'grow up' and embrace their roles as reproductive subjects, these schoolgirls challenge early modern expectations of age and of gendered behaviour. Yet as schoolgirls, this refusal is temporary. The masque's treatment of time reminds us that they are subject to the changes of time and the inevitable expulsion from the schoolroom. Nonetheless this potential future is foreclosed by the masque's conclusion. Cupid's Banishment closes with the return to the schoolroom in the final call for grace for pupils, teacher and school and in the implied return of the girls to the school when their performance has ended. It concludes with a celebration of the institution that has facilitated the girls' performance. The learning provided by the school and the opportunity for 'sweet', charming and pleasurable but chaste revels authorize the acts of rewriting, dance, song and speech through which the young pupils of Ladies' Hall negotiate the relationship between education and sexuality in their relation to their aged states. The figure of the schoolgirl controlling her own sexual development, agent in her use of education and at once subject to the time of the occasion but resistant to the developmental influences of aging becomes a powerful figure on this stage: a category of feminine youth or girlhood that stands in opposition to the social rites and apparently natural developments highlighted by fathers, educators and moralists as signifying the transition from childhood to adulthood. By returning to the schoolroom, these performers extend their girlhood in ways that, like Halberstam's ‘queer subcultural sites', ‘challenge the conventional binary formulation of a life narrative divided by a clear break between youth and adulthood'. ${ }^{76}$ They choose to remain in the queer space that enables such manipulation of time and the assertion of alternative futures that resist normative patterns of becoming an adult woman in early modern England.

\section{Redefining Childhood}


Both The Wit of a Woman and Cupid's Banishment present young females that occupy the liminal spaces between childhood and adulthood. The girls at Balia's school in The Wit of a Woman are negotiating the transition from the schoolroom to marriage and the pupils of Ladies' Hall in Cupid's Banishment are positioned between the institutions of the school and court and are depicted at the point of becoming sexually aware. It is the role assumed by these girls in making use of their education and their youth to determine this transition from girlhood or maidenhood to womanhood or to remain schoolgirls that is most striking. These young female characters and performers make their states as schooled girls serve their own ends. This is not depicted, as it is in many moral tracts, as a means of partaking in illicit sexual behaviour. Yet it is arguably more disruptive to the gendered and aged hierarchies of early modern England as it demonstrates the ways in which young women might manage their erotic desires and refuse the expected move to marriage and reproductive desire. Although the schoolgirls' agency ultimately leads to marriage in The Wit of a Woman, the celebration of chaste love in Cupid's Banishment and the decision to remain within the schoolroom with control for their own desiring and desirable bodies refuses (or at least defers) heteroerotic affirmation of their adult feminine identities. In this sense these girls begin to produce what would now be termed their queer subjectivities. ${ }^{77}$ Of course, the actions of the schoolgirls of Ladies' Hall are always facilitated by the author and schoolmaster, Robert White. In spite of pervasive debates on female education and misogynist orthodoxies that define the educated girl as transgressive reader and desiring subject, this performance suggests that there are opportunities within early modern culture for alternative articulations of girlhood - including the performance space created here by the schoolroom, the schoolmaster-advocate of female education and the masquing stage of Anna's court.

The active control of the schoolgirls in both performances over their own sexual identities potentially indicates that these figures are no longer children. Sexual maturity and knowledge are often depicted as one way of distinguishing between childhood and adulthood for early modern women. As noted above, Cupid invites the female students to enter a womanhood that he depicts in terms of sexual knowledge. In Shakespeare's Romeo and Juliet, a similar distinction is made between stages of the early modern woman's life cycle. The nurse recalls Juliet falling eleven years 
ago and her husband's comments 'dost thou fall upon thy face? / Thou wilt fall backward when thou hast more wit' and 'fall'st upon thy face? / Thou wilt fall backward when thou com'st to age'. ${ }^{78}$ The nurse's pun on Juliet becoming sexually active links this with wit, knowledge and coming of age. The implication that knowledge of sexual behaviour signals a movement away from childhood underpins the nurse's amusement when the three-year-old Juliet responded 'Ay'. This is perhaps because she was too young to understand but also signals Juliet's transitional state in the moment of the play as she echoes this childhood 'Ay' with her request to the Nurse to stop talking: 'And stint thou too, I pray thee, Nurse, say I'. ${ }^{79}$ In The Wit of a Woman and Cupid's Banishment the knowledge of a developing sexual maturity instead becomes the moment at which the schoolgirl characters deliberately choose to emphasise their youth and their schooling: to play 'girls'. As with Juliet, it is the acquisition of wit - hinting at sexual knowledge acquired at a particular age in these examples - that characterises the specific transitional moment from childhood to adulthood for the girls of The Wit of a Woman. However, like Juliet again, it is the use of this wit to control their own desires and broker their own marriages that renders them girls and allows them to manipulate this liminal space between childhood and adulthood - the space of school-girlhood - to challenge the wishes of their fathers. The deployment of wit by these female characters on the cusp of adulthood facilitates a disruptive renegotiation of what it means to enter adult heteronormativity in early modern society. It is not coincidental that these schoolgirls and Juliet are termed 'girls' ${ }^{80}$ This mediation of youthful female desire gestures towards a potentially queer girlhood, resistant to simplified understandings of an pre-sexual childhood leading to heterosexual adulthood, arranged and overseen by fathers. This potential, contained within The Wit of a Woman but limited by the play's concluding marriages, is realised in Cupid's Banishment when the schoolgirl performers use their knowledge to defer sexual experience. The performance of girlhood by schoolgirl characters who self-consciously 'play' girls on the professional stage and by schoolgirl players on the cusp of adulthood on the court stage thus demands a reconsideration of existing notions of what constitutes childhood in early modern culture. The schoolgirl performers illuminate what Kathryn Bond Stockton terms a queer childhood, one that incorporates temporal development and experience but that resists a transition to reproductive adulthood; a version of childhood that challenges both early 
modern and contemporary definitions of what it means to be a child. ${ }^{81}$ This childhood is inflected in these examples by the characters' and performers' gendered status. As girls, this momentary exploration and wilful assertion of their own desires is resistant to a female adulthood, which, in the patriarchal society of early modern England, similarly limited the agency permitted to them in the expression of sexual desire. Moreover, it is facilitated by the depiction of these youthful figures in and via the physical and imaginative space of the schoolroom. This version of a queer childhood is constructed in these plays as school-girlhood.

These texts are, therefore, productive resources for an examination of girlhood in the maledominated realm of early modern drama. Their dramatisations of the autonomy of female youths in asserting sexual, aged and gendered states demonstrates the extent to which girlhood is emerging as a distinct category related to youth in early seventeenth-century England. The language to account for the experiences of being a schoolgirl may not have fully evolved, but drama is engaging with this concept. The Wit of a Woman and Cupid's Banishment both bring the schoolgirl to the fore. They interrogate what this category means to those debating the pros and cons of female education; but they also suggest what it might be made to mean by young women at school in their performances of girlhood. These young girls assert original concepts of feminine behaviour related to their aged and educational states. Although this may be limited by the generic demands and metatheatrical allusions of The Wit of a Woman that ultimately locate boys rather than young women at the centre of the narrative and the performance, Cupid's Banishment demonstrates the possibilities of an assertive performance of girlhood that surpasses the temporal and spatial dimensions of the drama when schoolgirls are agents in the theatrical production. 
This research was supported by Australian Research Council's Discovery Projects funding scheme (Project ID: DP0988452). I would like to thank Kate Flaherty, Jennifer Higginbotham, Mark Johnston, William West and the anonymous readers of Renaissance Drama for their helpful suggestions.

${ }^{1}$ On the complexities of defining children, particularly the girl, see Kate Chedgzoy, 'Introduction: "What, are they children?”' in Shakespeare and Childhood, ed. Kate Chedgzoy, Susanne Greenhalgh and Robert Shaughnessy (Cambridge: Cambridge University Press, 2007), 15-31 (esp. 21); Jennifer Higginbotham, 'Fair Maids and Golden Girls: The Vocabulary of Female Youth in Early Modern English,’ Modern Philology 110 (2011): 171-96; Kristine Mourizi and Michelle Smith, ' Colonial Girlhood / Colonial Girls,' in Colonial Girlhood in Literature, Culture and History, 1840-1950, ed. Kristine Mourizi and Michelle Smith (Basingstoke: Palgrave Macmillan, 2014), 1-11 (esp. 1); Deanne Williams, Shakespeare and the Performance of Girlhood

(Basingstoke: Palgrave Macmillan, 2014), 4-6. On the challenges of recovering evidence pertaining to early modern children, see Kate Chedgzoy, 'Introduction: "What, are they children?”' 21; Andrea Immel and Michael Witmore, 'Introduction,' in Childhood and Children's Books in Early Modern Europe, 1550-1800, ed. Andrea Immel and Michael Witmore (New York: Routledge, 1996), 1-18 (esp. 6).

${ }^{2}$ Williams, 4, 6.

${ }^{3}$ Jennifer Higginbotham, The Girlhood of Shakespeare's Sisters: Gender, Transgression, Adolescence (Edinburgh: Edinburgh University Press, 2013), 9.

${ }^{4}$ For a useful overview of the relationship between female education and gender roles see Kathryn Moncrief and Kathryn McPherson, "'Shall I teach you to know?: Intersections of Pedagogy, Performance and Gender,' in Performing Pedagogy in Early Modern England: Gender, Instruction and Performance, ed. Kathryn Moncrief and Kathryn McPherson (Aldershot: Ashgate, 2013), 1-20. ${ }^{5}$ Kate Chedgzoy, 'A Renaissance for Children?' Newcastle Upon Tyne ePrints, http://eprint.ncl.ac.uk/pub_details2.aspx?pub_id=196398, deposited 20 Nov 2013, 19.

${ }^{6}$ Steven Bruhm and Natasha Hurley, 'Introduction,' in Curiouser: On the Queerness of Children (Minneapolis: University of Minnesota Press, 2004), ix-xxxviii (ix).

${ }^{7}$ See Annamarie Jagose, Queer Theory (New York: New York University Press, 1996), 3; Karin Lesnik-Oberstein, ‘Childhood, Queer Theory and Feminism,' Feminist Theory 11.3 (2010): 309321.

${ }^{8}$ John Johnson, The Academy of Love (London: Printed for Humphry Blunden, 1641), 18, 28. They are referred to as 'girles' on 15, 84 and 99, and as 'Damsell' on 87.

${ }^{9}$ Johnson, 14, 16, 18.

${ }^{10}$ Johnson, 99.

${ }^{11}$ On early modern debates on female education, see Constance Jordan, 'Feminism and the Humanists: The Case of Sir Thomas Elyot's Defence of Good Women,' Renaissance Quarterly 36.2 (1983): 181-201; Jane Stevenson, 'Women and Classical Education in the Early Modern Period,' in Pedagogy and Power: Rhetorics of Classical Learning, ed. Yun Lee Too and Niall Livingstone (Cambridge: Cambridge University Press, 1998), 83-109.

12 Juan Luis Vives, The Instruction of a Christian Woman (London: John Danter, 1592), C6r; A5r.

${ }^{13}$ Edward Hake, A Touchstone for this Time Present (London: Thomas Hacket, 1574), C3v-C4.

${ }^{14}$ See Helen Hackett, Women and Romance Fiction in the English Renaissance (Cambridge: Cambridge University Press, 2000), esp. 4-19; Lori Newcomb, 'Gendering Prose Romance in Renaissance England,' in A Companion to Romance: From Classical to Contemporary, ed. Corinne V. Saunders (Oxford: Blackwell, 2004), 121-139.

${ }^{15}$ Jacques Du Bosc, The Compleat Woman (London: Thomas Harper \& Richard Hodgkinson, 1639), 12-15.

${ }^{16}$ Vives, D1v. Amadis de Gaule formed the basis of Rachel Fane's schoolgirl translation exercises. See Caroline Bowden, 'The Notebooks of Rachael Fane: Education for Authorship?' in Early Modern Women's Manuscript Writing: Selected Papers from the Trinity/Trent Colloquium, ed. Victoria Burke and Jonathan Gibson (Aldershot: Ashgate, 2004), 157-180. On Ovid's status in 
Renaissance education, see Heather James, 'Ovid in Renaissance English Literature,' in A Companion to Ovid, ed. Peter Knox (Oxford: Blackwell, 2009), 423-441; Patricia Phillippy, “"Loytering in Love”: Ovid's Heroides, Hospitality, and Humanist Education in The Taming of the Shrew,' Criticism 40.1 (1998): 27-53 (esp. 33); Eve Sanders, Gender and Literacy on Stage in Early Modern England (Cambridge: Cambridge University Press, 1998), 63.

${ }^{17}$ William Shakespeare, The Taming of the Shrew, in The Norton Shakespeare, ed. Stephen Greenblatt and others (New York: W. W. Norton \& Company, 2008), 159-228 (3.1).

${ }^{18}$ Sasha Roberts, Reading Shakespeare's Poems in Early Modern England (Basingstoke: Palgrave Macmillan, 2003), 37-39.

${ }^{19}$ My argument is influenced by Judith Butler's seminal conceptualisation of gender as performative in the sense that it is produced via repetition of a series of behaviours and speech acts (see Gender Trouble [London: Routledge, 1999]). However, I am more interested in this essay in the performance of gender in the theatrical understanding of the term. For a discussion of the relationship between these terms see Andrew Parker and Eve Kosofsky Sedgwick, 'Introduction: Performativity and Performance,' in Performativity and Performance, ed. Andrew Parker and Eve Kosofsky Sedgwick (London: Routledge, 1995), 2-18. In reading theatrical performance as a site in which girlhood emerges, I follow the approach to childhood taken by Michael Witmore in Pretty Creatures: Children and Fiction in the English Renaissance (Ithaca: Cornell University Press, 2007) and to girlhood taken by Williams (see especially 6).

${ }^{20}$ See Chedgzoy, 'Introduction: "What are they children?”' 23-24; Naomi Miller and Naomi Yavneh, 'Early Modern Children as Subjects: Gender Matters,' in Gender and Early Modern Constructions of Childhood, ed. Naomi Miller and Naomi Yavneh (Aldershot: Ashgate, 2011), 114.

${ }^{21}$ Williams, 3.

${ }^{22}$ Higginbotham, ‘Fair Maids and Golden Girls’, 171-96. I am grateful to Dr Higginbotham for sharing early versions of this work with me.

${ }^{23}$ There are instances of earlier usages. The $O E D$ cites the earliest example of 'schoolgirl' as Richard Flecknoe's Enigmaticall Characters (1658). In Shakespeare's Measure for Measure, Isabella refers to her friendship with Juliet since 'schoolmaids' (in The Norton Shakespeare, 20482108 [1.4.46]).

${ }^{24}$ Judith Halberstam, In a Queer Time and Place: Transgender Bodies, Subcultural Lives (New York: New York University Press, 2005), 2.

${ }^{25}$ Notable exceptions include Caroline Bowden, 'Women in Educational Spaces,' in The Cambridge Companion to Early Modern Women's Writing, ed. Laura Lunger Knoppers (Cambridge: Cambridge University Press, 2009), 85-96; Dorothy Gardiner, English Girlhood at School: A Study of Women's Education Through Twelve Centuries (London: Oxford University Press, 1929), 141-280; Helen Jewell, Education in Early Modern England (London: Macmillan, 1998), 105-106; Josephine Kamm, Hope Deferred: Girls’ Education in English History (London: Methuen \& Co., 1965), 34-82; Rosemary O’Day, Education and Society 1500-1800: The Social Foundations of Education in Early Modern Britain (London: Longman, 1982), 179-195; Laetitia Yeandle, 'A School for Girls in Windsor,' Medieval and Renaissance Drama in England 17 (2005): 272-280.

${ }^{26}$ The Wit of a Woman (London: Edward White, 1604), Prologue, A2v. Further references are in the text. On the play's connections to Roman comedy, see Jean Lambert, 'Early Modern Educational Culture: The Wit of a Woman,' in Performing Pedagogy, 131-146 (133).

${ }^{27}$ Cited in Kenneth Charlton and Margaret Spufford, 'Literacy, Society and Education,' in The Cambridge History of Early Modern English Literature, ed. David Loewenstein and Janet Mueller (Cambridge: Cambridge University Press, 2002), 15-54 (16).

${ }^{28}$ See Bianca Calabresi, “'you sow, Ile read”: Letters and Literacies in Early Modern Samplers,' in Reading Women: Literacy, Authorship, and Culture in the Atlantic World, 1500-1800, ed. Heidi Brayman Hackel and Catherine Kelly (Philadelphia: University of Pennsylvania Press, 2008), 79104.

${ }^{29}$ On the subjects taught to early modern girls and the history of girls' schools, see footnote 25 above. 


\footnotetext{
${ }^{30}$ Richard Brome, The Queen and Concubine, in Five New Playes (London: For A. Crook and H. Brome, 1659), 87.

${ }^{31}$ Meg Lota Brown and Kari Boyd McBride, Women's Roles in the Renaissance (Portsmouth: Greenwood Publishing Group, 2005) note a level of parity in female education across social distinctions in that all girls were educated in domestic skills and female education was 'always designed to protect and preserve their chastity and virtue' (27). Of course, the range of subjects taught to girls did vary according to social status. See Norma McMullen, 'The Education of English Gentlewomen 1540-1640,' History of Education 6.2 (1977): 87-101. In addition, some women seemed to have access to exceptional educations, including Anne Clifford and Elizabeth Cary. See Lesley Peterson, 'Introduction,' in The Mirror of the Worlde: A Translation by Elizabeth Tanfield Cary, ed. Lesley Peterson (Montreal: McGill-Queen’s University Press, 2012), 32.

${ }^{32}$ On the relationship between early modern educational aims and the depiction of education in the play, see Lambert, 131-134.

${ }^{33}$ Lambert, 135.

${ }^{34}$ For other examples of schoolgirls construed as sisters pre-marriage, see Lambert, 135.

${ }^{35}$ Du Bosc, 12-15.

${ }^{36}$ See $O E D$; Williams, 5.

${ }^{37}$ Halberstam,153.

${ }^{38}$ The 1604 text contains so many errors in naming characters that it is impossible to determine the exact details of who falls in love with whom. W. W. Greg points out that to 'disentangle the confusion would practically mean editing the play, while it is extremely doubtful whether even the most drastic editing would serve to straighten matters out'. See W. W. Greg, Wit of a Woman (Oxford: Malone Society, 1913), vii-viii. Martin Wiggins persuasively suggests that the play may never have been finished and that the extant printed version is based on a copy sold to the printer when the dramatist gave up on it. I am very grateful to Dr Wiggins for sharing his forthcoming entry on the play for British Drama 1533-1642: A Catalogue (Oxford: Oxford University Press). The number of female protagonists and young characters, including the four schoolgirls and their four young suitors, suggests that if the play was performed casting would have depended on a high proportion of boy players, similar to Shakespeare's Love's Labour's Lost which required six boy actors (see T. J. King, Casting Shakespeare's Plays: London Actors and their Roles [Cambridge: Cambridge University Press, 1992]). The play also bears notable similarities to the drama of the children's playing companies during the opening years of the seventeenth century, particularly that of Thomas Middleton and George Chapman for the Children of Paul's and Children of the Chapel/Queen's Revels which commonly satirised old age through the depiction of the comic failure of old men in affairs of the heart. See Lucy Munro, Children of the Queen's Revels: A Jacobean Theatre Repertory (Cambridge: Cambridge University Press, 2005), 42; Edel Lamb, Performing Childhood in the Early Modern Theatre: The Children's Playing Companies (15991613) (Basingstoke: Palgrave Macmillan, 2008), 5.

${ }^{39}$ The suitability of boy actors to perform female roles on the early modern stage has been widely interrogated in scholarship. Seminal examples of this work are Jean E. Howard, 'Cross-dressing, the Theatre and Gender Struggle in Early Modern England,' Shakespeare Quarterly 39 (1988): 418-40; Stephen Orgel, 'Nobody's Perfect: Or Why Did the English Stage Take Boys for Women,' South Atlantic Quarterly 88 (1989): 7-29; Dympna Callaghan, Shakespeare Without Women (London: Routledge, 2000).

${ }^{40}$ Sally Mitchell, The New Girl: Girls’ Culture in England 1880-1915 (New York: Columbia University Press, 1995), 3.

${ }^{41}$ Jennifer Higginbotham has persuasively argued that while the term 'girl' opened up new positions for women outside traditional paradigms, the evolution of the language of female youth rendered this category less subversive. See Higginbotham, 'Fair Maids and Golden Girls'.

${ }^{42}$ Halbertsam, 152. Halberstam argues that this Western concept of adulthood is part of a larger understanding of the 'normal' that is upheld by a middle-class logic of reproductive temporality.

${ }^{43}$ Halberstam, 2.
} 
${ }^{44}$ Robert White, Cupid's Banishment, in Renaissance Drama by Women: Texts and Documents, ed. S. P. Cerasano and Marion Wynne-Davies (London: Routledge, 1996), 76-89 (1. 35). Further references are given in the text.

${ }^{45}$ Clare McManus, Women on the Renaissance Stage: Anna of Denmark and Female Masquing in the Stuart Court 1590-1619 (Manchester: Manchester University Press, 2002), 184.

${ }^{46}$ See Michael Shapiro, Children of the Revels: The Boy Companies of Shakespeare's Time and their Plays (New York: Columbia University Press, 1977), 1-11; Ursula Potter, 'Performing Arts in the Tudor Classroom', in Tudor Drama Before Shakespeare, 1485-1590, ed. Lloyd Kermode, Jason Scott-Warren and Martine Van Elk (Basingstoke: Palgrave Macmillan, 2004), 143-166.

47 See C. E. McGee, 'Cupid’s Banishment,' Renaissance Drama 19 (1988): 226-264.

${ }^{48}$ Elizabeth Cranfield, daughter of Lionel Cranfield and future Countess of Mulgrave, and her sister Mary Cranfield performed in the masque aged 10 and 7. See McGee, 259; Michael J. Braddick, 'Cranfield, Lionel, first earl of Middlesex (1575-1645),' Oxford Dictionary of National Biography, Oxford University Press, 2004 [http://www.oxforddnb.com/view/article/6609, accessed 27 May 2015]; C. H. Firth, 'Sheffield, Edmund, second earl of Mulgrave (1611-1658),' Oxford Dictionary of National Biography, Oxford University Press, 2004

[http://www.oxforddnb.com/view/article/25294, accessed 27 May 2015]. Anne Sandilands possibly the daughter of Sir James Sandilands and the goddaughter of the Queen (McGee, 259) would have been aged 12 at the time of the performance if she is the reason for the Queen and Prince Henry's Christening gifts to James Sandilands in 1605. See John Nichols, The Progresses, Processions, and Magnificent Festivities of King James the First, Vol 1(London: J. B. Nichols, 1828), 604.

${ }^{49}$ The anonymous The Office of Christian Parents (London, 1616) differentiates between the end of childhood for boys and girls, stating that it ranges from 'seven reacheth to fourteen, and to twelve in maides; because at that yeeres they beginne the flower of youth, preparing it selfe to the state of manhood or marriage' (L1r). For girls, therefore, marriage (legally permitted at 12) marks the end of childhood. Keith Thomas points out that although the legal age for marriage for women remained at 12, the average age of marriage for girls in the seventeenth century was mid 20s. See Keith Thomas, 'Age and Authority in Early Modern England,' Proceedings of the British Academy 62 (1976): 205-48 (225).

${ }^{50}$ See Sanders, 63-68.

${ }^{51}$ On the atypical features of this masque, see McManus, Women on the Renaissance Stage, 182188; Enid Welsford, The Court Masque (New York: Russell \& Russell, 1927), 197; Amanda Eubanks Winkler, 'Dangerous Performance: Cupid in Early Modern Pedagogical Masques,' in Gender and Song in Early Modern England, ed. Leslie C Dunn and Katherine R Larson (Aldershot: Ashgate, 2014), 77-92.

52 See McGee, 259; J. T. Peacey, 'Browne, Sir Richard, baronet (1605-1683),'

Oxford Dictionary of National Biography, Oxford University Press, 2004

[http://www.oxforddnb.com/view/article/3693, accessed 13 July 2010]; Ian Spink, 'Coleman, Charles (d. 1664),' Oxford Dictionary of National Biography, Oxford University Press, 2004 [http://www.oxforddnb.com/view/article/5869, accessed 13 July 2010].

${ }^{53}$ See Alison Findlay, Playing Spaces in Early Women's Drama (Cambridge: Cambridge University Press, 2006), 159-168; McManus, Women on the Renaissance Stage, 164-201; Clare McManus, 'Memorialising Anna of Denmark's Court: Cupid's Banishment at Greenwich Palace,' in Women and Culture at the Courts of the Stuart Queens, ed. Clare McManus (Basingstoke: Palgrave Macmillan, 2003), 81-100; Sophie Tomlinson, Women on Stage in Stuart Drama (Cambridge: Cambridge University Press, 2005), 38-47.

${ }^{54}$ Tomlinson, 39.

${ }^{55}$ McManus, Women on the Renaissance Stage, 184-186. See also Karen Britland, Drama at the Courts of Queen Henrietta Maria (Cambridge: Cambridge University Press, 2006), 96-98 on 'permitted female performance' and Kate Levin, 'Coming of Age on Stage: The Pedagogical Masque in Seventeenth-Century England,' George Herbert Journal 29.1-2 (2005): 114-130. ${ }^{56}$ Stephen Orgel argues that 'It is the relationship between the reality and the symbol, the impersonators and the impersonation, that is of crucial importance for the seventeenth-century spectator' of masques and draws a distinction between masquing, during which the performers are 
always recognised simultaneously as the fictional part and members of the court, and acting, which involves 'playing a role other than one's own'. See Stephen Orgel, 'Introduction,' in Ben Jonson: Selected Masques, ed. Stephen Orgel (New Haven: Yale University Press, 1970), 1-39 (5). See also Barbara Ravelhofer, The Early Stuart Masque: Dance, Music and Costume (Oxford: Oxford University Press, 2006), 170.

${ }^{57}$ For example, Lady Grace Mildmay recalls that her governess encouraged her to read William Turner's Herbal (1551). See Linda Pollock, With Faith and Physic: The Life of a Tudor Gentlewoman (London: Collins and Brown, 1993), 26. On emblem books for young women, see McManus, Women on the Renaissance Stage, 192-193.

${ }^{58}$ On the extent to which the female is allocated agency in dance, see Ravelhofer, The Early Stuart Masque, 118-120

${ }^{59}$ See Winkler, 85.

${ }^{60}$ Tomlinson, 41.

${ }^{61}$ On the definition of the girl in terms of intersecting discourses of gender, age and sex, see Catherine Driscoll, Girls: Feminine Adolescence in Popular Culture and Cultural Theory (New York: Columbia University Press, 2002), 7.

${ }^{62}$ Kate Chedgzoy, 'Playing with Cupid: Gender, Sexuality and Adolescence,' in Alternative Shakespeares 3, ed. Diana E. Henderson (London: Routledge, 2008), 138-157 (143).

${ }^{63}$ Ursula Potter, 'Greensickness in Romeo and Juliet: Considerations on a Sixteenth-Century Disease of Virgins', in The Premodern Teenager: Youth in Society 1150-1650, ed. Konrad Eisenbichler (Toronto: Centre for Renaissance and Reformation Studies, 2002), 271-291; Ursula Potter, 'Navigating the Dangers of Female Puberty in Renaissance Drama,' Studies in English Literature 1500-1900 53.2 (2013): 421-439; Ursula Potter, Roger Bartrop and Stephen Touyz, 'Pubertal Process and Greensickness in Renaissance Drama: A Form Fruste of Anorexia Nervosa?,' Australasian Psychiatry 17.5 (2009): 380-384.

${ }^{64}$ On the meanings of green in the Renaissance, see Bruce Smith, The Key of Green: Passion and Perception in Renaissance Culture (Chicago: University of Chicago Press, 2009), esp.75-6, 172175. Randall Nkayama points out that to give a woman a 'green gown' often had bawdy connotations, implying that the gown was stained from rolling around in the grass in "I know she is a courtesan by her attire": Clothing and Identity in The Jew of Malta,' in Marlowe's Empery: Expanding His Critical Contexts, ed. Sara Munson Deats and Robert A. Logan (Newark: University of Delaware Press, 2002), 150-163 (155). Edel Semple argues that green had various associations with youth, greensickness, happiness, lovers and whoredom in "Why, are we whores?"

Representations of Whoredom in Early Modern Literature, 1558-1649, PhD Thesis, University College Dublin, 2010. I am very grateful to Dr Semple for sharing her work with me.

${ }^{65}$ Mary Cranfield is listed as a wood nymph in the masque text, while her elder sister Elizabeth is included among Diana's nymphs.

${ }^{66}$ This is context is prioritised in Findlay, 159-162. On female performance in early modern convents, see Elissa Weaver, Convent Theatre in Early Modern Italy (Cambridge: Cambridge University Press, 2002).

${ }^{67}$ See Theodora Jankowski, Pure Resistance: Queer Virginity in Early Modern English Drama (Philadelphia: University of Pennsylvania Press, 2000), esp. 26.

${ }^{68}$ Jankowski, 4.

${ }^{69}$ Barbara Ravelhofer, “Virgin wax” and "hairy men-monsters”: Unstable Movement Codes in the Stuart Masque,' in The Politics of the Stuart Court Masque, ed. David Bevington and Peter Holbrook (Cambridge: Cambridge University Press, 1998), 244-272.

${ }^{70}$ Lauren Shohet raises the possibility Cupid's Banishment might be part of a wider tradition of performance by girls' schools when she places it in a tradition of later performances of masques in schools (including Thomas Jordan's Cupid His Coronation [1654]) and suggests that the text's uniqueness might consist of 'having survived in textual form, rather than its having occurred at all'. See Reading Masques: The English Masque and Public Culture in the Seventeenth Century (Oxford: Oxford University Press, 2010), 49.

${ }^{71}$ Caroline Bicks, 'Reading the Jesuitess in A Game at Chess,' Studies in English Literature 49.2 (2009): 463-484; Caroline Bicks, 'Producing Girls on the English Stage: Performance as Pedagogy 
in Mary Ward's Convent Schools,' in Gender and Early Modern Constructions of Childhood, 139153.

${ }^{72}$ Kathryn Bond Stockton, The Queer Child, or Growing Sideways in the Twentieth Century (Durham: Duke University Press, 2009), 13.

73 Jankowski, 6.

${ }^{74}$ For an insightful summary of such theoretical approaches, see Claudia Castaneda, Figurations: Child, Bodies, Worlds (Durham: Duke University Press, 2002), 147.

${ }^{75}$ Castaneda, 4

${ }^{76}$ Halberstam, 161, 153.

${ }^{77}$ See Eve Kosofsky, 'Queer Performativity: Henry James’ The Art of the Novel,' GLQ 1 (1993): 116.

${ }^{78}$ William Shakespeare, Romeo and Juliet, in The Norton Shakespeare, 897-972 (1.3.43-44; 1.3.5758). I would like to thank Donna Long for her suggestions here.

${ }^{79}$ Shakespeare, Romeo and Juliet, 1.3.60.

${ }^{80}$ On the use of 'girl' to refer to Juliet, see Williams, 43.

${ }^{81}$ Stockton, 13. 